\title{
Structural Proteins of Reoviruses
}

\author{
P. C. LOH$^{1}$ aND A. J. SHATKIN \\ Laboratory of Biology of Viruses, National Institute of Allergy and Infectious Diseases, National Institutes of \\ Health, Bethesda, Maryland 20014
}

Received for publication 20 August 1968

\begin{abstract}
Polyacrylamide gel electrophoresis of the solubilized proteins from the three serotypes of reovirus revealed that each contained three major and four minor components. Subviral particles were prepared by brief treatment of complete virions with urea. Electron microscopy, density-gradient centrifugation, and chemical analyses of these particles indicated that their outer capsid structure had been selectively removed. They contained only two proteins, but their ribonucleic acid composition was similar to that of complete virions. The subviral particles were not infectious.
\end{abstract}

The reovirus group includes three serological types which share a common complement-fixing antigen but are distinguishable by neutralization and hemagglutination-inhibition reactions (15). Electron microscopic examination of purified reovirus particles has shown that all serotypes consist of three principal morphological components: (i) the outer capsid, (ii) an inner structural layer, and (iii) a core containing the viral ribonucleic acid (RNA; 9, 13, 26). In contrast to the extensive information available on the properties of the double-stranded, segmented genome and the adenine-rich RNA of reoviruses $(1-3,20,28)$, their structural proteins have not been characterized. The present investigation was undertaken to analyze and compare the proteins of all three serotypes and to relate them to the morphological features of purified virions.

\section{Materials and Methods}

Cells and viruses. Mouse L-929 cells were grown in suspension or stationary culture in Eagle's medium supplemented with $5 \%$ fetal calf serum. Reovirus types 1 (Lang), 2 (D-5 Jones), and 3 (Abney) were obtained from the American Type Culture Collection. The procedures for reovirus infection of cells and virus purification have been described $(18,19)$.

Preparation of radioactive virus. Monolayer cultures of $\mathrm{L}$ cells were infected at an input multiplicity of 1 to 10 plaque-forming units per cell. After a 3-hr adsorption period, fresh medium containing $2 \%$ fetal calf serum, one-tenth the usual concentration of amino acids, and $0.1 \mu \mathrm{c}$ of reconstituted ${ }^{3} \mathrm{H}$-labeled protein hydrolysate per ml (Schwarz Bio Research Inc., Orangeburg, N.Y.) were added. The cells were incubated at $37 \mathrm{C}$ for 2 to 4 days, harvested, and the

\footnotetext{
${ }^{1}$ Present address: Department of Microbiology, University of Hawaii, Honolulu.
}

virus was purified. Similar procedures were employed for the preparation of ${ }^{32} \mathrm{P}$-labeled virions, except that phosphate-free medium was employed (20).

Solubilization of virions. Purified virus suspended in phosphate-buffered saline at a protein concentration of 150 to $500 \mu \mathrm{g} / \mathrm{ml}$ was degraded by treatment with $2 \%$ sodium dodecylsulfate (SDS), 1\% 2-mercaptoethanol (ME), and $8 \mathrm{M}$ urea for 2 to $3 \mathrm{hr}$ at room temperature. The samples, dialyzed for 2 to $3 \mathrm{hr}$ against $0.1 \% \mathrm{SDS}, 0.1 \% \mathrm{ME}$, and $8 \mathrm{M}$ urea in $0.01 \mathrm{M}$

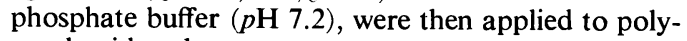
acrylamide gels.

Polyacrylamide-gel electrophoresis. Gels were made as described previously (24) and consisted of $10 \%$ acrylamide, $0.26 \% \mathrm{~N}, N^{\prime}$-bis-methylene acrylamide, $0.1 \%$ SDS, and $0.1 \mathrm{M}$ phosphate buffer $(p \mathbf{H} 7.2)$. Samples (100 to $300 \mu \mathrm{g}$ ) of viral protein in 0.05 to 0.2 $\mathrm{ml}$ of buffer containing $10 \%$ sucrose were electrophoresed for 16 to $24 \mathrm{hr}$ at 4 mamp per gel at $20 \mathrm{C}$. After electrophoresis, the gels were fixed in $10 \%$ trichloroacetic acid, stained with $0.025 \%$ Coomassie blue, and destained in $7 \%$ acetic acid (11). Gels containing radioactive proteins were frozen, sliced, solubilized in $\mathrm{H}_{2} \mathrm{O}_{2}$, and counted (21).

Preparation of subviral particles (SVP). Among the several methods tested, it was found that the outer capsid component could be selectively removed from the complete virion by treatment with $4 \mathrm{M}$ urea in phosphate-buffered saline for $3 \mathrm{~min}$ at $4 \mathrm{C}(8,25)$.

The SVP were then separated by isopycnic sedimentation in $\mathrm{CsCl}$ solutions.

Immunodiffusion. The double gel-diffusion method of Ouchterlony was carried out as described by Campbell et al. (5). Antireovirus chick sera for all three serotypes were kindly supplied by Philip Coleman of the Communicable Disease Center, Atlanta, Ga. The antisera had titers of $1 / 1,280$ by hemagglutinationinhibition reaction; with heterologous serotypes, the titers were less than $1 / 10$.

$R N A$ and protein analysis. Orcinol (12) and Lowry (10) procedures were employed to measure RNA and protein, respectively. The base composition of viral 
RNA was analyzed according to the method of Salzman and Sebring (16).

\section{RESUltS}

Polyacrylamide-gel electrophoresis of viral proteins. Purified preparations of all three reovirus serotypes were dissociated by treatment with SDS, ME, and urea, and the resulting solubilized protein mixtures were examined by electrophoresis in $10 \%$ polyacrylamide gels. The staining patterns included three major bands (I, II, and IIIb) and four minor bands (M1, 2, 3, and IIIa; Fig. 1). One of the minor bands (M3) was absent or difficult to detect with type 3 virions. Reovirus type 3 was also labeled with ${ }^{3} \mathrm{H}$-amino acids and was analyzed; the distribution of radioactivity closely resembled the staining patterns (Fig. 2). The proportion of total radioactivity in each of the major components was: I, $20 \%$; II, $31 \%$; and III, which included a poorly resolved minor band (a) and a faster, major component (b), $27 \%$. The other minor bands comprised the remaining protein. This method probably provides a good estimate of the relative amount of protein in each of these components, since the virions were labeled with a mixture of $16{ }^{3} \mathrm{H}$-amino acids.

The molecular weights of the various viral

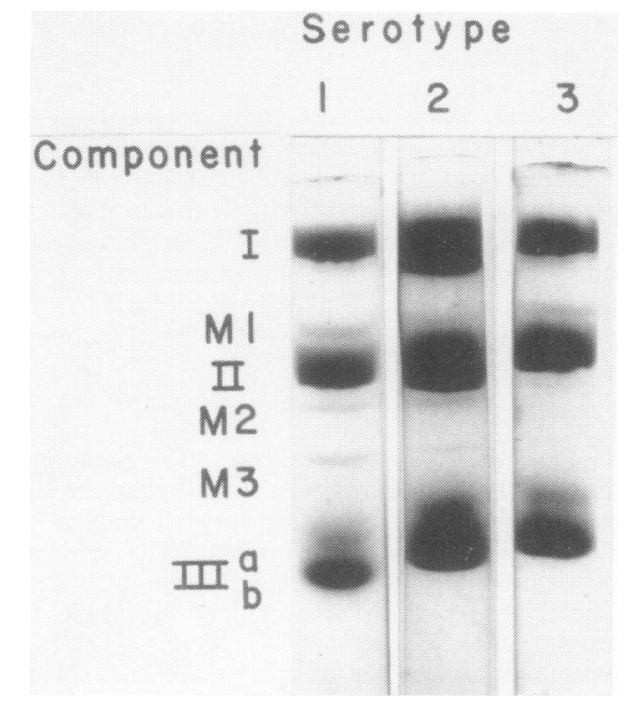

Fig. 1. Analytical polyacrylamide-gel elctrophorograms of the dissociated proteins of reovirus types 1,2 , and 3. Purified virus was solubilized as described in Materials and Methods, and applied to $10 \%$ gels. Electrophoresis was for $24 \mathrm{hr}$ at 4 mamp per gel. After electrophoresis, the gels were fixed in $10 \%$ trichloroacetic acid, stained with Coomassie brilliant blue dye, and destained by repeated washing with $7 \%$ acetic acid. The origin (cathode) is at the top of the gels.

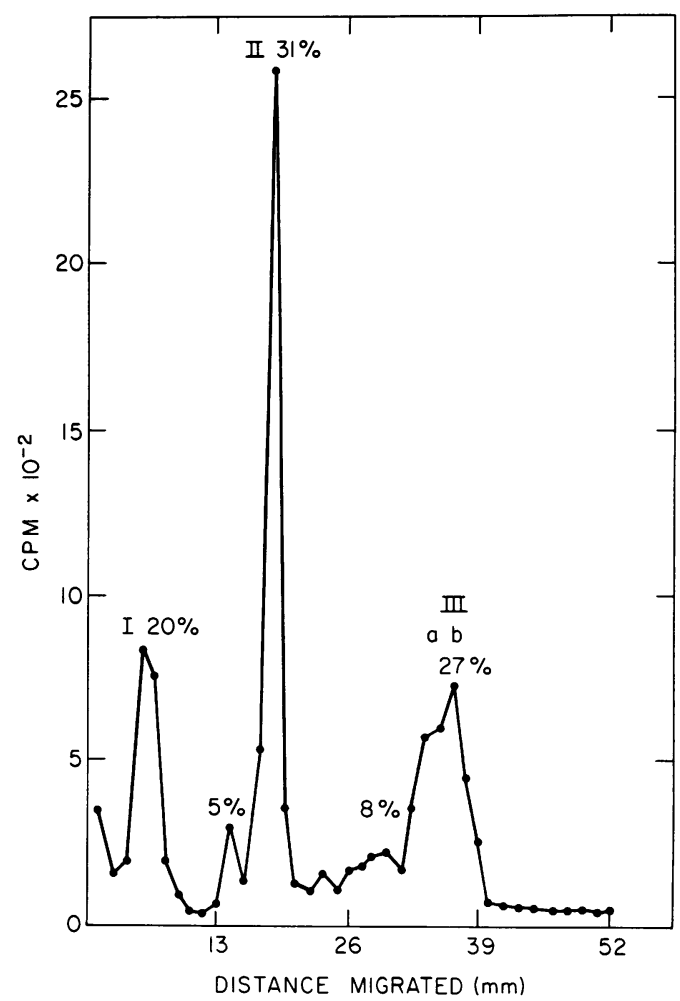

FIG. 2. Polyacrylamide-gel electrophorograms of dissociated proteins from purified reovirus type 3 labeled with ${ }^{3} \mathrm{H}$-amino acids. Migration from left to right (anode).

proteins were determined by comparing their electrophoretic mobilities with those of proteins of known molecular weights: ovalbumin $(45,000)$ and bovine serum albumin $(67,000)$. It was estimated that components I, II, IIIa, and IIIb have molecular weights of $>100,000,83,000,44,000$, and 40,000 , respectively. Electrophoresis of the solubilized proteins in $10 \%$ gel containing $8 \mathrm{M}$ urea yielded no additional bands, indicating that reaggregation did not occur when analyses were performed in the absence of urea. Electrophoretic patterns similar to those in Fig. 1 were also obtained with proteins from phenol-dissociated particles, except that the four minor bands were more readily seen with type 3 virus.

Immunological analysis. The immunological reactivity of the solubilized proteins of all three serotypes was investigated by the Ouchterlony double gel-diffusion method. The proteins formed a minimum of two distinct precipitin lines with their respective homologous antisera (Fig. 3). Similar bands were also obtained with heterologous antisera. 

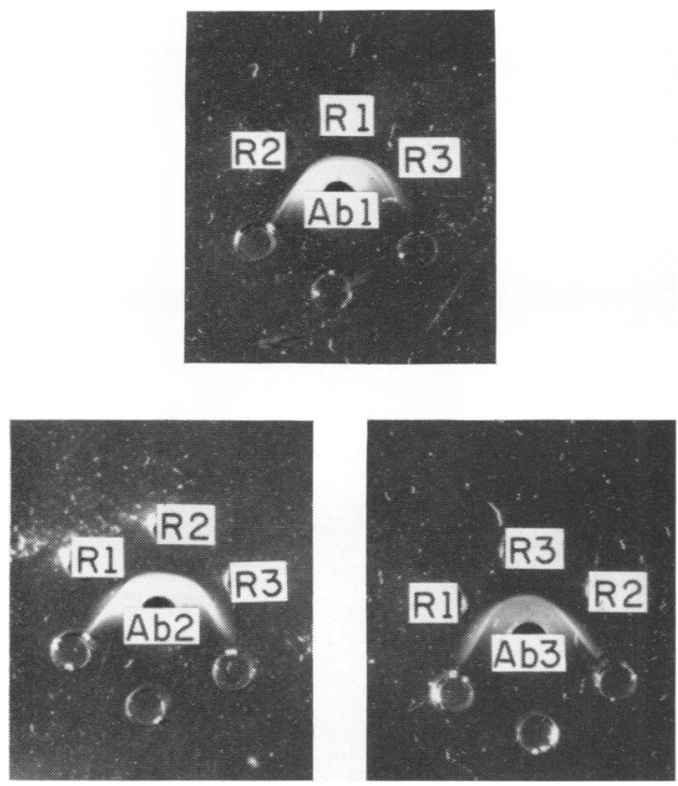

FIG. 3. Immunodiffusion of solubilized protein preparations from reovirus serotypes $1(R 1), 2(R 2)$, and $3(R 3)$. Center wells contain antisera against serotypes $1(A b 1), 2(A b 2)$, and $3(A b 3)$.

Selective degradation of the virion. It was of interest to relate the proteins separated by gel electrophoresis to the structural components of reovirus particles. Previously it was reported that the capsids of some animal viruses could be disaggregated by heat treatment (14), but attempts to remove the outer structural layer of purified reoviruses by heating were unsuccessful. Incubation at 52 or $56 \mathrm{C}$ for different periods ( $30 \mathrm{~min}$ to $3 \mathrm{hr}$ ) in the presence of different amounts of $\mathrm{NaCl}(0.01$ to $0.1 \mathrm{M})$ did not alter the composition of the particles as determined by buoyant density in $\mathrm{CsCl}$ and gel electrophoresis.

Of the several other procedures tested, the most effective method for removing the outer capsid structure selectively was brief exposure to $4 \mathrm{M}$ urea at $4 \mathrm{C}$. The buoyant density in $\mathrm{CsCl}$ of ${ }^{32} \mathrm{P}$-labeled type $3 \mathrm{SVP}$ prepared by urea treatment was $1.46 \mathrm{~g} / \mathrm{cm}^{3}$ (Fig. 4). Similar values were obtained with ${ }^{3} \mathrm{H}$-amino acid-labeled type 3 virus or with nonradioactive reovirus types 1 and 2. Since whole virus particles have a buoyant density of $1.37 \mathrm{~g} / \mathrm{cm}^{3}$, SVP obtained by this method could be readily separated from complete virions by isopycnic sedimentation in $\mathrm{CsCl}$. The increased density of SVP was due to the removal of most of the viral protein with retention of the RNA.

Electron microscopic examination of the par- ticles purified by $\mathrm{CsCl}$ density-gradient centrifugation revealed that the diameter of ureatreated particles (SVP) was $45 \mathrm{~nm}$ as compared to $70 \mathrm{~nm}$ for whole virions (Fig. 5). The SVP had the size and structure expected for reovirus particles with their outer capsid removed.

The solubilized proteins of SVP were analyzed by polyacrylamide-gel electrophoresis. Only components I and IIIa were present (Fig. 6). The predominant intermediate band (II) and component IIIb, as well as the several minor components associated with the complete virion, were absent from the SVP. The staining patterns were corroborated with ${ }^{3} \mathrm{H}$-labeled viral protein preparations (Fig. 7). The electrophoretic pattern of solubilized proteins from the complete type 3 virion is shown in Fig. 7A. Components $I$, II, and IIIa and b were all present. After urea treatment, the particles of buoyant density 1.46 $\mathrm{g} / \mathrm{cm}^{3}$ in $\mathrm{CsCl}$ contained only the slowly migrating component I and component IIIa (Fig. 7B). Intermediate band II, component IIIb, and the minor components were recovered from the top portion of the $\mathrm{CsCl}$ gradient (Fig. 7C). These findings strongly suggest that components II, IIIb, and the minor components comprise the outer capsid of the complete virion. The small quantity of component I, also found at the top of the gradient, probably resulted from completely degraded particles.

The amount of viral protein recovered from the ${ }^{3} \mathrm{H}$-labeled SVP was $31 \%$; of the total added,

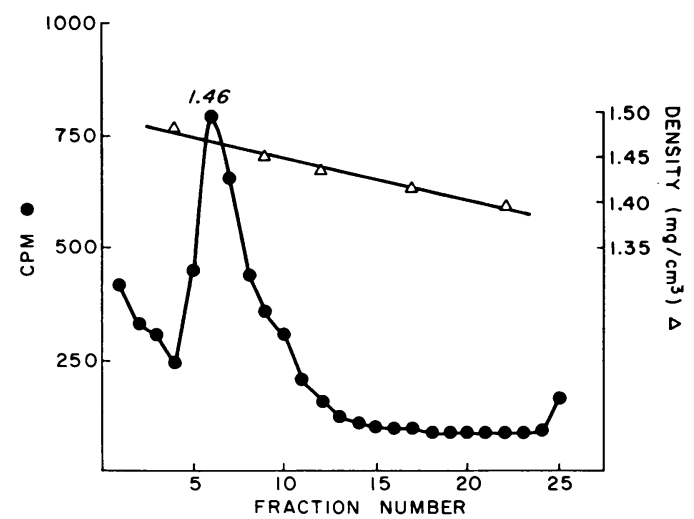

FIG. 4. Isopycnic sedimentation of SVP in CsCl. Purified ${ }^{32} P$-labeled reovirus type 3 preparations were exposed to 4 is urea for $3 \mathrm{~min}$ at $4 C$, diluted with a solution of $\mathrm{CsCl}$ to a density of $1.425 \mathrm{~g} / \mathrm{cm}^{3}$, and centrifuged at 33,000 rev/min for $24 \mathrm{hr}$. Samples were collected from the bottom of the centrifuge tube, and the radioactivity insoluble in $5 \sigma_{c}$ trichloroacetic acid at $4 C$ was counted on membrane filters in liquifluortoluene. 

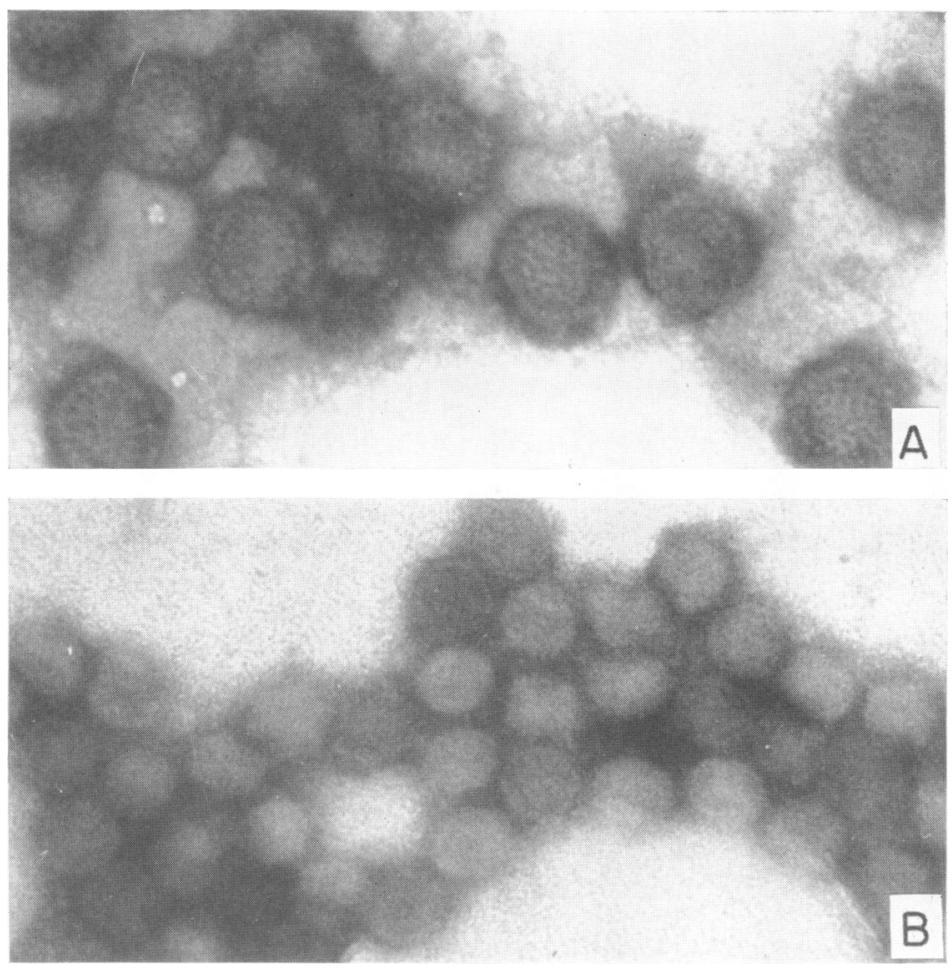

FIG. 5. Negatively stained preparations of reovirus type $3(A)$ and $S V P(B) . \times 175,000$.

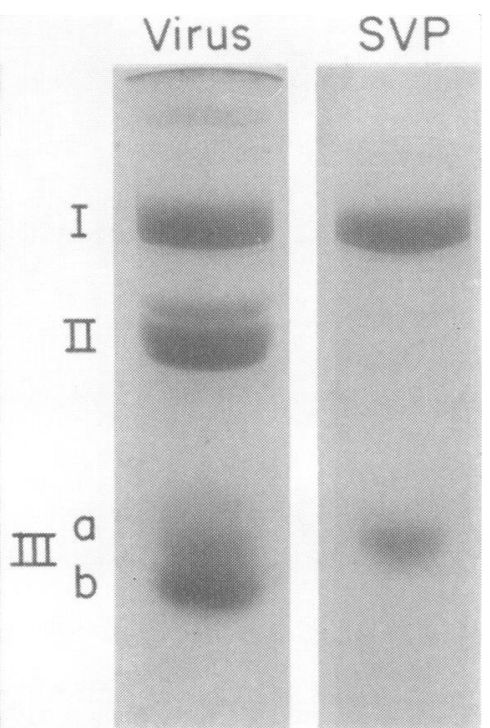

Fig. 6. Analytical polyacrylamide-gel electrophorograms of the dissociated proteins from reovirus type 3 (whole virus) and SVP. The procedures for solubilization of the proteins, gel electrophoresis, fixation and staining are described in the text and Fig. 1. The origin (cathode) is at the top of the gels. indicating that $69 \%$ of the protein is present in the outer capsid of the complete virion. This is in good agreement with the results of chemical analysis in which $27 \%$ of the total protein was recovered in the SVP (Table 1). In contrast, almost $80 \%$ of the viral RNA remained associated with the SVP. The base composition of the SVP RNA of each of the three serotypes was similar to those of the complete virions, indicating that both the double-stranded RNA and the single-stranded, adenine-rich ribopolymer were present in all preparations (Table 2). However, adenine-rich RNA was apparently lost from the SVP to a slightly greater extent than doublestranded RNA, as shown by the reduced levels of adenylic acid in SVP. The RNA was also extracted from SVP with phenol and examined by polyacrylamide-gel electrophoresis as described previously (21). The 10 double-stranded RNA segments were present in the same relative proportion as in whole virus particles.

\section{Discussion}

The structural proteins of the three reovirus serotypes are similar qualitatively. At least seven protein components can be separated by gel electrophoresis from particles which have been 
solubilized by treatment with phenol or SDS, $\mathrm{ME}$, and $8 \mathrm{M}$ urea. Furthermore, electrophoresis in the presence or absence of $8 \mathrm{M}$ urea yielded similar patterns, suggesting that the different

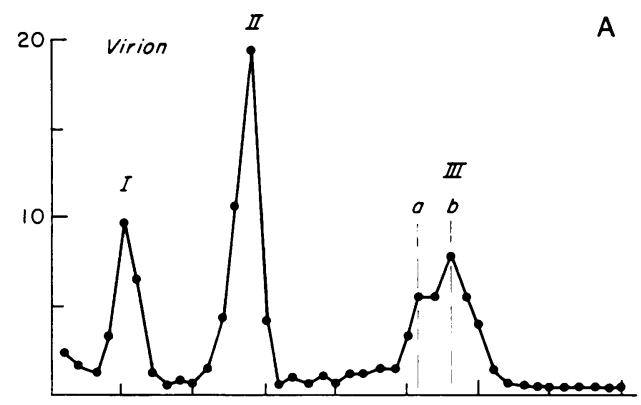

B
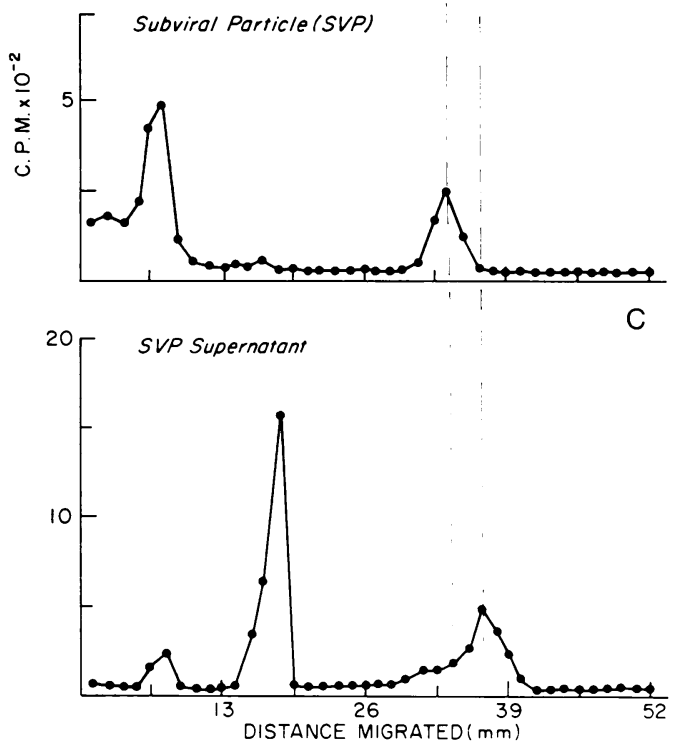

FIG. 7. Polyacrylamide-gel electrophorograms of dissociated proteins derived from whole virus $(A), S V P$ $(B)$, and $S V P$ supernatant fraction $(C)$. SVP were produced from purified reovirus type 3 labeled with ${ }^{3} \mathrm{H}$ amino acids. They were sedimented in $\mathrm{CsCl}$ as described in the text and Fig. 4. The CsCl solution above the band of SVP (SVP supernatant) was dialyzed against several changes of 0.01 is phosphate buffer ( $p H$ 7.2) and concentrated to the original virus sample volume before solubilization and electrophoresis.
TABLE 1. RNA and protein content of type 3 reovirus and $S V P$

\begin{tabular}{c|c|c|c|c}
\hline Reovirus & R.YA & Remaining & Protein & Remaining \\
\cline { 5 - 5 } & $\mu g$ & $\%$ & $\mu g$ & $\%$ \\
Virion ..... & 342 & & 1,932 & \\
SVP........ & 269 & 79 & 520 & 27 \\
\hline
\end{tabular}

bands are not protein aggregates. In contrast to components I and II, the molecular weights of components IIIa and IIIb are in the size range of the structural proteins of polyoma, Sindbis, and poliovirus $(4,23 ; R$. E. Fine and W. T. Mirakami, Federation Proc., p. 616, 1968). Reaction with iodoacetamide to prevent reformation of disulfide bonds (17) and amino acid analysis of the protein bands should help establish whether the various protein bands are distinct polypeptides or oligomers.

The solubilized reovirus proteins retained their immunological reactivity. However, they crossreacted with heterologous, type-specific immune sera, indicating that the dissociation of the virion results in a loss of type specificity. This loss may be due to the destruction of a specific protein(s) involved in the immunological reaction. Alternatively, the serological type-specificity may result from the spatial arrangement of the native proteins in the mature virion.

The selective removal of the outer capsid from the complete virion by treatment with urea apparently reflects a difference between the binding forces involved in the arrangement of the protein subunits in the outer capsid versus the innerlayer structure. The nature of these differences remains to be elucidated. At least five protein components, representing $70 \%$ of the viral protein, are present in the outer capsid, whereas only two proteins, or about $30 \%$ of the total, are in the SVP. One of these may be a basic protein associated with the viral nucleic acid.

Although 10 to $20^{\prime} c$ of the adenine-rich, single-stranded ribopolymer is lost after exposure to urea, the base composition analyses indicate that most of it remains associated with the SVP. This finding indicates that the ribopolymer is present within the virion rather than adsorbed to the surface of the capsid.

TABLE 2. Base composition of reovirus and SVP $R N A^{a}$

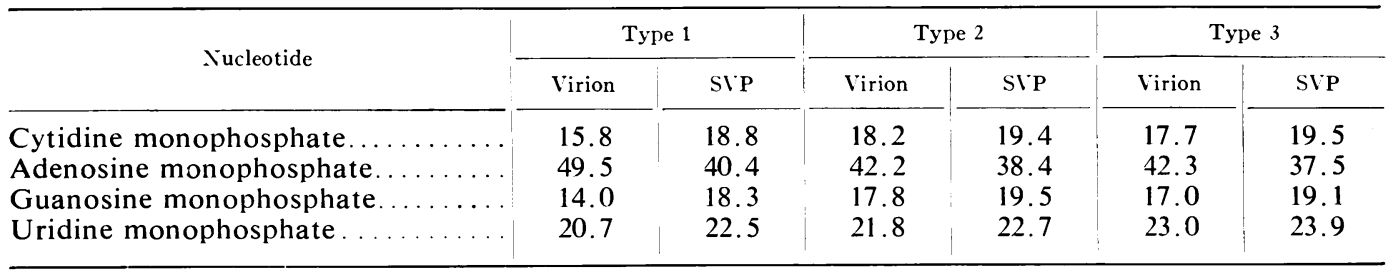

\footnotetext{
a Values are expressed as moles per cent.
} 
Proteolytic digestion of some strains of reovirus has been reported to result in the formation of subviral particles with an enhanced infectivity (22). However, the SVP produced by urea treatment were noninfectious, presumably due to an effect of the denaturing agent on the SVP. Noninfectious subviral particles have been isolated from infected cells and produced by treating virions with sodium pyrophosphate (7). Such preparations have a higher ratio of protein to RNA and a lower buoyant density in $\mathrm{CsCl}$ $\left(1.41 \mathrm{~g} / \mathrm{cm}^{3}\right)$ than urea-treated SVP. Unlike the urea-treated SVP, they retain remnants of capsomeres on their surface.

The molecular weight of the reovirus genome is about $15 \times 10^{6}$ daltons $(21,25$; W. Millward, Y. Watanabe, and A. F. Graham, Bacteriol. Proc., p. 172, 1968), a size sufficient to code for a large number of proteins. In the present investigation, a minimum of seven structural proteins were found. Since the viral genome is composed of 10 different fragments $(21 ; \mathrm{W}$. Millward, Y. W. Millward, Y. Watanabe, and A. F. Graham, Bacteriol. Proc., p. 172, 1968), it will be of interest to determine which of the fragments contain information for the synthesis of structural proteins.

\section{ACKNOWLEDGMENT}

We thank M. David Hoggan of this Institute for the electron micrographs. One of us (P.C.L.) is a recipient of a Public Health Service Special Research Fellowship (1-F3-A18592).

\section{Literature Cited}

1. Bellamy, A. R., L. Shapiro, J. T. August, and W. K. Joklik. 1967. Studies on reovirus RNA. I. Characterization of reovirus genome RNA. J. Mol. Biol. 29:1-17.

2. Bellamy, A. R., and W. K. Joklik. 1967. Studies on reovirus RNA. II. Characterization of reovirus messenger RNA and of the genome RNA segments from which it is transcribed. J. Mol. Biol. 29:19-26.

3. Bellamy, A. R., and W. K. Joklik. 1967. Studies on the A-rich RNA of reovirus. Proc. Natl. Acad. Sci. U.S. 58:1389-1395.

4. Boeyé, A. 1965. Molecular weight of a poliovirus protein. Virology 25:550-559.

5. Campbell, D. H., J. S. Garvey, N. E. Cremer, and D. H. Sussdorf. 1963. Methods in immunology, p. 143. W. A. Benjamin, Inc., New York.

6. Dunnebacke, T. H., and A. K. Kleinschmidt. 1967. Ribonucleic acid from reovirus as seen in protein monolayers by electron microscopy. Z. Naturforsch. 222b:159-164.

7. Gomatos, P. J. 1967. RNA synthesis in reovirusinfected L-929 mouse fibroblasts. Proc. Natl. Acad. Sci. U.S. 58:1798-1805.

8. Granboulan, N., and A. Niveleau. 1967. Etude au microscope électronique du RNA du reovirus. J. Microscopie 6:23-30.

9. Loh, P. C., H. R. Hohl, and M. Soergel. 1965. Fine structure of reovirus type 2. J. Bacteriol. 89:1140-1144.

10. Lowry, O. H., N. J. Rosebrough, A. L. Farr, and R. J. Randall. 1951. Protein measurement with the folin phenol reagent. J. Biol. Chem. 193: 265-275.

11. Maizel, J. V. 1966. Mechanical fractionation of acrylamide gel electrophorograms: radioactive adenovirus proteins. Science 151:988-990.

12. Mejbaum, W. 1939. Über die Bestimmung kleiner Pentosemengen, insbesondere in Derivaten der Adenylsäure. Z. Physiol. Chem. 258:117-121.

13. Muller, G., C. C. Schneider, and D. Peters. 1966. Zur Feinstruktur des Reovirus (Typ 3). Arch. Ges. Virusforsch. 19:110-122.

14. Russell, W. C., R. C. Valentine, and H. G. Pereira. 1967. The effect of heat on the anatomy of the adenovirus. J. Gen. Virol. 1:509-522.

15. Sabin, A. B. 1959. Reovirus: a new group of respiratory and enteric viruses formerly classified as ECHO type 10 is described. Science 130:1387-1389.

16. Salzman, N. P., and E. D. Sebring. 1964. An improved procedure for measuring the distribution of $\mathrm{P}^{32} \mathrm{O}^{4}$ among the nucleotides of ribonucleic acid. Anal. Biochem. 8:126-129.

17. Shapiro, A. L., E. Vinuela, and J. V. Maizel. 1967. Molecular weight estimation of polypeptide chains by electrophoresis in SDS-polyacrylamide gels. Biochem. Biophys. Res. Commun. 28:815-820.

18. Shatkin, A. J. 1965. Inactivity of purified reovirus RNA as a template for $E$. coli polymerases in vitro. Proc. Natl. Acad. Sci. U.S. 59:1721-1728.

19. Shatkin, A. J., and B. Rada. 1967. Reovirus-directed ribonucleic acid synthesis in infected $L$ cells. J. Virol. 1:24-35.

20. Shatkin, A. J., and J. D. Sipe. 1968. Singlestranded, adenine-rich RNA from purified reoviruses. Proc. Natl. Acad. Sci. U.S. 59: 246-253.

21. Shatkin, A. J., J. D. Sipe, and P. C. Loh. 1968. Separation of ten reovirus genome segments by polyacrylamide gel electrophoresis. J. Virol. 2: 986-991.

22. Spendlove, R. S., and M. E. McClain. 1968. In M. Sanders and E. H. Lennette (ed.), Medical and applied virology, proceedings of the Second International Symposium, p. 127-130. Warren H. Green, Inc., St. Louis.

23. Strauss, J. H., Jr., B. W. Burge, E. R. Pfefferkorn, and J. E. Darnell, Jr. 1968. Identification of the membrane protein and core protein of sindbis virus. Proc. Natl. Acad. Sci. U.S. 59: 533-537.

24. Summers, D. F., J. V. Maizel, and J. E. Darnell. 1965. Evidence for virus-specific noncapsid proteins in poliovirus-infected HeLa cells. Proc. Natl. Acad. Sci. U.S. 54:505-513. 
25. Vasquez, C., and A. K. Kleinschmidt. 1968. Electron microscopy of RNA strands released from individual reovirus particles. J. Mol. Biol. 34: 137-147.

26. Vasquez C., and P. Tournier. 1962. The morphology of reovirus. Virology 17:503-510.

27. Watanabe, Y., L. Prevec, and A. F. Graham.
1967. Specificity in transcription of the reovirus genome. Proc. Natl. Acad. Sci. U.S. 58:10401046.

28. Watanabe, Y., and A. F. Graham. 1967. Structural units of reovirus ribonucleic acid and their possible functional significance. J. Virol. 1:665-677. 